\title{
THE IMPACT OF SINGLE-PARENT FAMILIES' SOCIAL VULNERABILITIES ON CHILDREN
}

\author{
lleana VARGA \\ University of Oradea, The Departament of Social Science, Doctoral School of \\ Sociology, Oradea, Romania \\ ileanavarga@yahoo.com
}

\begin{abstract}
The current work describes the single-parent family in theory from the perspective of the vulnerable social group, which requires state intervention for protection and specialized and adapted support. The characteristics of social vulnerability and the types of vulnerabilities are being presented synthetically in order to identify the vulnerability of the social group of the single-parent family. Among elements of vulnerability of the single-parent family a special presentation is given to those that negatively impact the shaping of children character educated amidst such groups, as they emerge from the specialized studies on the matter. We are aiming the low academic achievement of such children, more prevalent criminal behaviour, integration problems in the school environment and in the students' group, features that may be influenced by the absence of a parent, by financial and emotional problems of family members. The single-parent family stands for a social unit with a more and more prevalent identification in contemporary society, which makes up for a legitimate object of interest as to knowing data on its functionality, the difficulties it faces, the quality of its relations with society, the positive and negative elements that mark childrens' life. The profile of the single-parent family and membership to this type of family may have an influence through destructured internal family social capital, so that the family's structural deficiencies, family relations that do not match an optimal family environment, lead to medium and long-term effects on child development. By acknowledging the effects of family structure on the behaviour of single-parent family children, a certain framework of potential actions and steps may be outlined which can provide them with a safety net and can ensure them with the fundamentals of an adequate social, academic and professional life. On the ground of shared responsibility, this approach must involve all significant actors that have potential of active and proactive involvement in relation to the issue of children from single-parent families.
\end{abstract}

Key words: social vulnerability, single-parent family, social inclusion, social exclusion, educational implications.

Jel Codes: Z13; 120

\section{Introduction}

The societal traits (the political regime, legislation, general educational standards, social policies, level of economic development) hallmark the way in which families perform their role. The globalization process obviously impacts today's standard of living, triggering essential change both in the structure and the functioning of social institutions, family and school level included. Due to its status, the family needs to 
provide relevant response to challenges in the contemporary world in terms of family life settlement, its effectiveness, especially in what children's education is concerned.

Family is the outmost social institution, in which the temporal and cultural factor makes the difference. As an institution, the family gives individuals a chance to adapt and evolve on the social hierarchy. In this perspective, the nuclear family as a social system, performs several basic functions: integration, adaptation, goal achievement, values preservation, keeping of cultural models (Chipea, 2000, p.37). Family structure fulfils one important function in every society: most children in developed countries are being raised within a family, although the type of that family may change during their lifetime. A family generally provides a child with opportunities to become a stable and self-sufficient individual, like, for instance, getting him access to school education. Children's future rate of success heavily depends on the household in which they are being raised. Nevertheless, a child cannot choose his/her family and is bound to accept a hypothetical situation in which his/her family is not able to provide him/her with the best opportunities.

Family structure has been deeply altered during the last half of the $20^{\text {th }}$ century. The second demographic transition which has occurred since the 60' s through the end of the 80's in the developed countries, has implied the decreasing of the fertility rate, that of marriage, an increase in the divorce rate, and an increase in childbirth in the case of single women, determining thus an increase in terms of single-parent families. The traditional model of a married couple with one or more children relying on the father who caters for the family while the mother runs the household and looks after the children is no longer self-evident in the developed countries. This results in more and more children being raised in an unstable family (De Lange, Donkers et. Wolbers, 2014, 329-350).

The single-parent family " is an asymmetrical family structure consisting of a single parent and his/her child/children, as a a result of either death of the other parent, or of divorce, or of one of the parent's leaving the family, or of the parent's decision of not getting married, or of the decision to adopt made by a single person, or of unintended pregnancy ( and childbirth ) in an open-relationship, especially in the case of teenage parents (Mitrofan et. Ciuperca, 1997, p.41). One specific feature in defining the single-parent family aims at its functional capability. The nuclear family fulfils or tends to fulfil its society impacting roles (the socializing, the biological, the educational, the economic and the affective functions), while the single-parent family, due to its structural incompleteness, may find itself in various difficulty instances, being unable to fulfil the roles that naturally incur to the family structure.

\section{Social vulnerability and its characteristics}

Vulnerability has a multidimensional character which needs to be analyzed in connection with elements of the economic context and the degree of access to resources. Thus, vulnerability is being identified and analyzed at both the individual and the collective level, as well as at the societal level. Vulnerability occurs in connection with a series of factors which contribute to its occurrence and to its persistence, following that vulnerable groups are being more or less affected by it. The social environment, with its economic, cultural, political dimensions may stimulate social vulnerability, or it may contribute to its continuation. In this context, the awareness of the role of social barriers acting with respect to the process of change is important. " The vulnerable group means people or families that are at 
risk of losing their ability to cater for their daily life needs, due to medical condition, disability, poverty, drug or alcohol addiction or other such situations leading to economic and social vulnerability (Law no. 292/ 2011, art. 6. P)

Approached on a broad acception, one may identify vulnerability either at the communication, cognition, institutional, relational, economic or social level....

Cognitive and communicational vulnerability

This type is ascribed to individuals which may not have the ability to grasp the gist of the information they receive and thus cannot act rightfully and conscientiously in their future demeanours. Cognitive vulnerability may refer to individuals who may find themselves in various situations and in the position to make a quick judgement, while for a certain period of time they cannot make use of their capabilities. To this category may belong people who are hospitalized, sedated, stressed, or otherwise hindered in their ability to grasp or participate to various studies or activities. On the other hand, communicational vulnerability comprises within its range such individuals that lack the ability to understand or decide, thus being unable to participate to various research stages, studies or other diverse activities. Under this heading one may include people who cannot understand or speak the language in which the conversation is being acted.

Institutional vulnerability

This type of vulnerability may refer to individuals who have decisional ability but are unable to speak out, their freedom of speech being limited due to the formal environment in which they have to act.

Social/informal subordination determined vulnerability

Individuals ascribed to this type of vulnerability may have a subsidiary position with respect to another person (for instance women who may participate to an activity or conversation, but do not do so as they take into account their husbands' unwillingness ).

Medical vulnerability

Under this heading we may group very ill patients or those who perceive their being part of a study or experiment as being their only chance of getting well. Due to this condition, the patients take virtually no consideration to the risks they are facing, being bound to take full part due to their precarious state.

Economic vulnerability

Economic vulnerability refers to impoverished people, those living in precarious conditions, as well as to low-income people who may find difficulties in accessing food or health care.

Social vulnerability

It is a way of perceiving certain groups, thus triggering their discrimination, depriving their respective members by disregarding their contribution to society. Being part of these groups equals to having a precarious material condition, with no possibility to make it by yourself, more often than not resorting to social care.

We are dealing with social vulnerability when the state of potentiality leads to deprivation specifically due to the lack of achievement of opportunities needed for change. Social issues of vulnerable groups, that is of those groups in which vulnerability has transitioned from the state of potentiality to that of actual reality, are being addressed by some authors in terms of social constructionism, a sociological approach that values the idea that people build realities in the context of interactions (Cojocaru, 2005, pp. 22-42). " Social constructionism inquiry focuses mainly on explaining processes by which people describe, explain or interpret the 
world in which they live (including themselves)" (Gergen, 1985, p.266).

\section{The impact on children of single-parent family as vulnerable social group, from the perspective of specialized studies}

We hold the single-parent family as a vulnerable social group at risk of social exclusion and we will be analyzing it from this perspective (Stanciu, 2008).

Analyzing the issue of social exclusion and inclusion implies the awareness of such elements of the social and economic context and of the individuals' living standards. Be they makers or executors of policy, it is important for each of them to concentrate their effort to take responsibility of the efficient social risk management and of the implied intervention. At the same time, we are pointing out the need of key actors' involvement with unitary and agreed mechanisms and instruments in a formally organized frame.

In this respect one of the main actors is the family.

The educational implications on children from single-parent families are among the most emphasized. Sociological studies on single-parent families show that schooling in educational institutions with high rate of single-parent family children negatively impacts childrens' academic performance, notwithstanding the educational institution's socio-economic status, size or environment (De Lange, Dronkers et Wolbers, 2014; Woessmann, 2015). The negative correlation between single-parent families and children's educational performance that studies have pointed out in the United States is no particular case, on the contrary it may be extended to almost every Western nation. Therefore, the possible explanations for this negative correlation should be general enough as to apply to all countries, not only to the US. This should mean that along with the classical variable of the socioeconomic composition of schools (which has been constantly emphasized) there are other indicators that point out to the interdependent and substantial relation to educational performance, such as the rate of single-parent families. Research has also shown that quality teachers' shortage negatively impacts pupils' educational performance, an indicator which is strongly associated with singleparent families, as they are frequently compelled to move house to poorer neighbourhoods after divorce or family breakdown. In some countries, such as the US, school resource is significantly correlated with the fiscal resource of various disticts or neighbourhoods.

As far as the impact on children of single-parent family characteristics is concerned, various outcomes of single-parent families' children's cognitive development may be identified. Besides the realization that raising in a singleparent family negatively impacts pupils' academic achievement, irrespective of their way of assessment ( PISA tests scoring, school grades, high school graduation, extent of schooling... ), studies have also targeted the assessment of the impact on children's behaviour of such single-parent families' features as (some of which we will be analyzing hereby ): the gender of the parent in charge of the child's raising and education, the sex of children raising in single-parent families, parents' involvement in children's academic activity.

Thus, some studies (Lee, Kushner \& Cho, 2007) may difference the issue in correlation with the parent raising the children in a single-parent household. The Lee, Kushner \& Cho study has made use of a national database in order to examine the outcome of parent gender, children's sex and parents' involvement in schooling on various indicators of academic achievement of pupils from single- 
parent families.

First of all, the results of the above mentioned study may indicate there is no significant variation in academic achievement between teenagers living in singleparent households along with their mother and teenagers living in single-parent households with their father, thus invalidating results of previous studies. Some previous research had signaled most children living with single mothers recorded higher rates of academic achievement (Featherma, Hauser, 1978), just like other research had reported that children living with single fathers reached higher level of academic success (Mulkey, Crain, Harrington, 1992). Secondly, by looking at the correlation between the gender of parents and the child's gender, the study has shown no significant variation with respect to academic achievement between teenagers living with same-sex parent and teenagers living with a parent of the opposite sex.

This outcome contradicts the theoretical foundation underpinning the argument of the same-sex parent. Thirdly, the results found by Lee, Kushner \& Cho may indicate the fact that no significant difference has been shown between teenagers having lived with strongly involved single parents and teenagers having lived with less involved single parents. Sons having lived with single fathers, sons having lived with single mothers and daughters having lived with single mothers recorded the same or lower rate of academic achievement irrespective of low or high level of parental involvement, daughters having lived with single fathers alone recorded higher rates of academic achievement whilst their single fathers have been more involved in their academic activities. That is to say daughters having lived with single parents showing high level of parental involvement have scored.

Better than any other group on the four variables of academic success being studied.

The question then arises as to why daughters having lived with single parents showing high level of parental involvement score better than other groups as far as the academic achievement is concerned?

The explanations to this outcome brought by the above mentioned authors argue that when children and teenagers see their parents as friends parental authority is being compromised, endangered either by excessive identification to the same-sex parent, or by being too much deactivated with the parent of the opposite sex, as suggested by the specialized studies on development of gender identity. There ought to be certain boundaries between parents and children, in order to differentiate them from friends or other acquaintances, the authors argue. Previous research may indicate that fathers are less likely to become friends with their daughters than with their sons, having reported a certain uneasiness as to the inception of secondary sexual characteristics during teenage. Fathers are more compatible with sons, as they are abler to identify with the inception of male teenage from their own experience. The modelling effect of parents, differentiated by gender distance, may explain the fact that daughters having lived with single fathers with high level of parental involvement have scored higher in terms of educational performance, in the occurrence fathers may feature the characteristics of both parent and "coach", unlike a friend or confidant. Fathers may not identify with their daughters in terms of their social and interpersonal interests the way mothers may. Fathers's focus is more task-driven, in the occurrence on the educational performance, while mothers act in a more wholistic way, so as to being more tolerant and less demanding with respect to the task. In other words, the 
"instrumental" role of fathers and the "socio-affective" role of mothers may appear more evident with respect to girls.

Longitudinal studies have also been carried out on cognitive and behavioural outcomes of children from various types of single-parent families.

Studies carried out by Carlson and Corcoran (2001) have been paradigmatic in this respect in which they used data from the National Longitudinal Survey of Youth in the USA in order to inquire the impact of various family structures in a longitudinal way, on both behavioural and cognitive outcomes of 7 to 10 years old children. The above mentioned authors have explored four possible mechanisms by which family structure may impact children. Children's outcomes , they noted, vary along economic resources, parental socialization, childhood stress and mother's psychological mood. The survey extends previous research to four dimensions. The study has focused thoroughly on cognitive outcomes by making use of more recent data from national surveys, which has allowed the researchers to also include children of older mothers, and thus make use of a more representative sample in terms of mother age. Several mechanisms by which family structure might impact children performance have been explored and also the way family structure impacts behavioural as well as cognitive outcomes has been examined, which has allowed comparing and contrasting the impact of family structure.

\section{Conclusions}

Of all the above studies' outcomes, we may synthesize the following:

- Children living for a longer period of time in a single-parent family are more likely to show poor behavioural and cognitive outcomes, than children living for a shorter period of time in such single-parent families, an inference that corroborates such data recorded by other surveys that have also been shown in the current as well as in the previous documents

- Children raised in single-parent family structures show since birth and throughout the highest risk of developing inadequate behaviour and reaching below average academic achievement

- The above mentioned differences are constant, as long as only children's characteristics are controlled the family structure has big and significant initial impact: as opposed to children from two-parent families, children from any other type of family structures show a higher rate of behavioural issues and significantly lower scores in cognitive tests. When support measures to mothers' mental wellbeing are included, the scope of the initial impact of family structure shrinks by a third or even by more for the behavioural issues rate. Additional income, on the other hand, reduce the scope of the impact of family structure on both behaviour and cognitive outcomes, while in the final model almost all the consequences of family structure reach very low and unimportant standards once adequate income and a positive mental state are being ensured.

- Gender is an important predictor as far as the children's behavioural outcomes are concerned: girls feature less behaviour issues.

- Mothers' mental health is important to children behaviour; depression risk is being associated with a higher rate of behaviour issues, while adequate life management (control) is associated with fewer problems for children. 
- Income is strongly and negatively associated with behaviour issues, while quality family time is associated with fewer behaviour issues

- Cognitive results of children are mirrored statistically only through mathematical data. Children from deprived environments generally score less than children from normal environments.

- Girls score significantly higher in reading tests, although no difference has been recorded for the mathematics tests.

- Low birth weight is being associated with lower scores in mathematics tests

- Mothers' economic status is a strong predictor of both cognitive results (reading and maths), while mothers' level of education and mental health show no correlation whatsoever.

- Income has a significantly positive impact on scores reached in reading and Maths, while the quality of home environment has a strong impact on mathematical ability and a significant impact on reading skills.

The conclusions to be drawn are likely to be similar in many respects to those signaled by previous research. Also, the survey made by the two authors shows that there are many effects of some variables stemming from the family structure which are being reduced or eliminated when a series of control variables are being included. Mothers' educational score is a strong predictor of cognitive results, just like income is a predictor especially in the case of reading scores. Although research has found that all impact of family structure on mathematical performance has vanished as soon as other control variables (income, material condition, mental health etc.) have occurred, in the case of the two tests - maths and reading - several effects have been persistent, some of which have not demonstrated the expected way.

Certainly, the single-parent family and children from its specific environment may show various elements of vulnerability, with respect to social behaviour, social integration, school integration and school performance, juvenile crime, drug consumption, emotional level. Membership of single-family group significantly impacts children education and development, not only the awareness of its effects, but also the identification and the implementation of intervention measures aiming at their protection being very much needed.

\section{References:}

1. Carlson, M. J., \& Corcoran, M. E. (2001). Family structure and children's behavioral and cognitive outcomes. Journal of marriage and family, 63 (3), 779-792.

2. Chipea F. (2001), Familia contemporană. Tendințe globale și configurații locale, Editura Expert București

3. Cojocaru, Ş. (2004), Abordarea problemelor sociale din perspectiva vulnerabilităţii sociale. Revista de Cercetare şi Intervenţie Socială. vol. 5. Holt România şi Universitatea „Al.I.Cuza”. Departamentul de Sociologie şi Asistenţă Socială. Editura Lumen. Iaşi. pp.657-658.

4. Cojocaru, Ș. (2005), Metode apreciative în Asistența socială. Ancheta, supervizarea și managementul de caz", Editura Polirom, lași

5. De Lange, M., Dronkers J., Wolbers, M. H.J., (2014), Single parent family forms and childrens educational performance in a comparative perspective 
effects of schools, share of single-parent families Radboud University Nijmegen The Neterlands

6. Gergen, K.J. (1985), The social constructionism movement in modern psychology, American Psychologist, 40 (3), pp. 266-275

7. Lee, S. M., Kushner, J., \& Cho, S. H. (2007), Effects of parent's gender, child's gender, and parental involvement on the academic achievement of adolescents in single parent families. Sex Roles, 56 (3-4), 149-157.

8. Lee, D., \& McLanahan, S. (2015), Family structure transitions and child development: Instability, selection, and population heterogeneity. American sociological review, 80 (4), 738-763

9. Mitrofan I., Ciupercă, C. (1997), Psihologia relațiilor dintre sexe, Editura Alternative, București

10. Stanciu, M. (coord.) (2008), Condiții de viață ale familiilor cu copii din România, București, Institutul de Cercetare a Calității Vieții

11. Woessmann, L. (2015). An international look at the single-parent family; family structure matters more for US students. Education Next, 15 (2), 4250.

12. http://cometc.unibuc.ro/subiecti-vulnerabili.html

13. Legea asistenţei sociale nr. 292/2011, publicată în Monitorul Oficial, Partea I, nr. 905 din 20.decembrie 2011 